\title{
CONFOUNDING LETHE IN THE MOYOLA: HEANEY, VIRGIL AND THE CULTURAL UNCONSCIOUS
}

\author{
Eugene O'Brien ${ }^{1 \times}$ \\ ${ }^{1}$ University of Limerick, Sreelane, Limerick, Ireland
}

\begin{abstract}
This essay discusses Seamus Heaney's 'Route 110', from Human Chain, as an example of life writing as embodied in the very specific genre of poetry. His use of Virgil's Aeneid Book VI as a type of cultural unconscious is examined, and each of the works are viewed as tesserae, which are brought together as a type of mosaic through translation and a dual perspective. Heaney has described this poetic sequence as an attempt to translate parts of Book VI of the Aeneid. 'Route 110' is also read in the light of Heaney's book-length posthumous translation of Aeneid Book VI, and all three texts cohere and combine to form the mosaic of significant aspects of his life, as seen from an older perspective. The sequence is read in terms of the connection between the two books as an attempt to explore aspects of Eros and Thanatos in his own writing

Key Words: Seamus Heaney; 'Route 110'; Aeneid Book VI; tessera; mosaic; unconscious; memory; translation
\end{abstract}

\footnotetext{
Senior lecturer, and Head of the Department of English Language and Literature in Mary Immaculate College, University of Limerick, Ireland, and is also the director of the Mary Immaculate Institute for Irish Studies. He is the editor for the Oxford University Press Online Bibliography project in literary theory, and of the Routledge Studies in Irish Literature series. His more recent books include Seamus Heaney as Aesthetic Thinker (Syracuse University Press); The Soul Exceeds its Circumstances: The Later Poetry of Seamus Heaney (Notre Dame University Press); Recalling the Celtic Tiger, with Eamon Maher and Brian Lucy (Peter Lang) and Representations of Loss in Irish Literature, with Deirdre Flynn (Palgrave). He is currently working on a monograph on the writing of Paul Howard, a co-edited book on Irish poetry and climate change (with Andrew Auge) and a co-edited book on the reimagining Ireland series. Email: Euggene.Obrien@mic.ul.ie. ORCID ID: 0000-0001-5970-967X.
} 
The need to tell one's story - to use the conventions of narrative to put a shape on a life lived; on mistakes made; on decisions taken - is something that transcends genre, period and social class. Life writing, in any genre, transcends or blurs the distinction between the performative and constative, and it also hazes the distinction between the epistemological categories of fact and interpretation. The actions, triumphs, failures, and moments of significance in a life are connected, but the processes of selecting and ordering such connections are often as interesting as what they are trying to communicate. The connected moments that come together in life writing could be seen to parallel the visual construction of a mosaic, where hundreds or thousands of small tiles, or what the Romans used to call tesserae, are carefully put together so that when viewed as a whole, they each contribute to a broader shape of which they themselves are only one segment. The place of each tessera can only be judged by someone who has a transcendental perspective on the mosaic as a whole.

However, to write a life is a more complicated process, as this transcendental perspective on one's past is clouded by the processes of memory, and by the unconscious. Often, if memories are traumatic or difficult, we repress them into our unconscious, and are not able to readily recall them, even though these repressed memories can often be a significant symptomatic influence in our lives. The unconscious has generally been seen as something that resides within the individual human being, but Freudian and psychoanalytic theory has always been keen to stress that the unconscious is also created by our cultural context: it is what Sigmund Freud has called a sort of "internal foreign territory" (Freud, 1933, 57), and what Jacques Lacan termed an extimité (extimacy): "the extimate is both what is closest to me and radically external to me, me and not me, in me more than me" [italics original] (Lacan, 1992, 139). For both of these thinkers, the unconscious is both an individual and a socio-cultural construct: "the unconscious is outside" (Lacan, 1977, 123), Lacan notes, and he sees this outside as constitutive of the individual, who is dependent as an individual subject "on a pre-existing order, the symbolic" (Easthope, 1999, 136). The unconscious, then is "that aspect of me which I cannot know about myself, but which nevertheless makes me what I am" [italics original] (Thwaites, 2007, 6). Language has no direct access to the unconscious and yet it is in many ways the only way in which we can know the unconscious.

Clearly this complicates the process of life writing, as to extend our tessera metaphor, it is like trying to work out where the tesserae go without being able to see the whole mosaic. The Irish poet John Hewitt acknowledged something of the potential problematics in attempting to write an overall account of any life in a pamphlet in 1967, which was entitled Tesserae, appropriately enough, and he went on to give his 1981 collection the title Mosaic. In this poem, Hewitt argues that those "bystanders accidentally involved" in historical events should be recognized, along with those who seem to be the main players, the "soldier, functionary, rebel": 
History is selective. Give us instead the whole mosaic, the tesserae, that we may judge if a period indeed has a pattern and is not merely a handful of coloured stones in the dust. (Ormsby, 1991, 313-314)

Hewitt's point is that the pattern is in the perspective. In this essay, I will be probing this assertion, not in the case of a period, but in the case of a person, in this instance a poet, who has also written about "innocent bystanders", namely Seamus Heaney. In "Mycenae Lookout", he says:

\author{
No such thing \\ as innocent \\ bystanding, (Heaney, 1996, 30)
}

suggesting that we are all involved in what we experience in some manner. For both Heaney and Hewitt, "history itself is made up of different pieces", and "the relation of the parts to the whole, as well as the actual coherence of the whole, remains finally unclear" (Matthews, 1997, 50). The same, I will argue, is true of the story of an individual. Attempting to write one's life necessarily involves choices and selection, and this is not always a conscious process, as some of the most significant and primal experience that shape us as people may well have been repressed at an early age so that, like a black hole, we can see their effects but never themselves. Just as our lives are made up of different tesserae, so life writing is as if a group of the tesserae were attempting to write the history of the mosaic itself, but from its own limited perspective as one of these "small pieces of marble or coloured stone" (Evans, 2005, 444) that make up the pattern of a mosaic.

The relationship between the tesserae and the mosaic is analogous to that of the events of a life and the act of life writing in some ways, but not in others. Interestingly, given that we are discussing the life writing of a poet, someone who has chosen a genre where the polysemic nature of words is foregrounded, the word "tessera" has another meaning. Hans Georg Gadamer speaks of the "tesserae hospitalis, a clay emblem, broken between host and guest in Greek society on the occasion of a social gathering. When host and guest meet again they 'recognize' each other by presenting their fragment token of a pre-existing whole" (Singer, $2003,75)$. It served as a way of bridging temporal and spatial discontinuities, and of offering a moment of recognition between people who were connected but had never actually met:

The host presented his guest with the so-called tessera hospitalis by breaking some object in two. He kept one half for himself and gave the other half to his guest. If in thirty or fifty years' time, a descendant of the guest should ever enter his house, the two pieces could be fitted together again to form a whole in an act of recognition. (Gadamer, 1986, 31) 
Lacan offers an overview of the tessera in Écrits (2006). The notion of recognition and of connection is central to both meanings of the term: as part of the mosaic, it is the interconnection of the tesserae that give the shape its ontology; as a token of recognition, the connection between the two broken pieces of the tessera brings forth a whole, which is then symbolic of a connection that had been hitherto unknown:

A tessera is a small tablet or die used by the ancient Romans as a ticket, tally, voucher, means of identification, or password. The tessera was used in the early mystery religions, where fitting together again the two halves of a broken piece of pottery was used as a means of recognition by the initiates, and in Greece the tessera was called the sum bolon. A central concept involved in the symbol is that of a link. (Lacan Écrits 786)

Given that we are talking about a poet, whose core expertise is the linking of words through both conscious performative discourses like syntax and grammar, as well as unconscious chains of association which often focus on the sound and rhyme of words as much as on their meaning, the etymology of the tessera and its link to that of the symbol is highly significant. It suggests that connections are at the core of symbolic thinking, and Heaney, in one of his later poetic sequences, foregrounds this by establishing a series of connections and symbolic links between aspects of his own life and a second-hand book purchased when he was a student. I am referring to "Route 110" from Human Chain (2010), a poem which references Virgil's Book VI of the Aeneid (2006) throughout, and which tells aspects of Heaney's own life journey under the twin poles of Eros and Thanatos: love and death.

This poetic sequence has ten sections, and each section is comprised of a twelve-line poem. Nobuaki Tochigi has made the point that this form, which has been used quite a lot in Heaney's middle and later poetry, constitutes "Heaney's continuous practice in the sonnet form [that] resulted in the 12 iambic lines" (Tochigi, 1994, 73), so these can be viewed as foreshortened sonnets, with the summative couplet missing. Given that the poems are about a life journey, the championing of process over summation would seem to be thematically appropriate. The form of these sonnets is a variation of Dante's terza rima, poems of twelve lines divided into four three-line stanzas. The original terza rima is a verse form composed of rhymed iambic tercets whose rhyme scheme is: $a b a b c b$ $c d c$ ded. The second line of each tercet sets the rhyme for the following tercet, thus supplying the verse with a common thread, which is a way to link the stanzas in a visual and verbal mosaic. Heaney does not follow this rhyme scheme however, and his tercets are largely unrhymed, or "tercets with off rhymes" (Heininger 63), and are often written in a form of loose iambic pentameter in lines of ten to twelve syllables. Structurally, this means that the poems are formal fields of force, and by this, I mean that the syntax is broken up by the stanzaic structure. Most of the stanzas use enjambment, but some are end-stopped for closure. It means that the thought and image chain can flow across each poem, but is also broken up 4 times 
across the twelve lines, which makes quite short poems formally, syntactically and rhythmically quite complex. Interestingly, Bernard O'Donoghue has noted that "Heaney's terza rima seems to me to be his most impressive achievement in poetic form" (O'Donoghue, 1994, 99), and as we will see, this form compliments the theme and perspective. Heaney's first sustained use of the form is to be found in Station Island (1984).

In this sequence, he is offering a backward look over his life, and he is articulating his own life in tandem with that of Virgil, and his own work in tandem with that of the Aeneid, Book VI. These form the two broken segments of the tessera, and the connection is initiated when he is standing looking down at an actual mosaic on the floor of Saint Columb's College in Derry:

Quercus, the oak. And Quaerite, Seek ye. Among green leaves and acorns in mosaic (Our college arms surmounted by Columba

Dove of the church, of Derry's sainted grove) The footworn motto stayed indelible: Seek ye first the Kingdom... (Human Chain 5)

The motto in question is in Latin Quaerite Primum Regnum Dei ("Seek ye first the Kingdom of God"), and in the mosaic, it surrounds acorns and oak leaves and is presided over by the dove, the tesserae of each tile come together to become a mosaic. Here, in parvo, we see the poetic method at work in Heaney's ongoing juxtaposition of his own lived experience with his experience of Latin literature. The mosaic allows for all of these connections to be made, and the Latin motto is the hinge that allows for the entrance of Virgil. St Columb's "named for the patron saint of the oak wood" (Heaney, 1987, 2), was the place where Heaney first encountered Latin, as he notes in "Alphabets":

Declensions sang on air like a hosanna

As, column after stratified column,

Book One of Elementa Latina,

Marbled and minatory, rose up in him. (The Haw Lantern 1)

It was here that he was taught by Fr Michael McGlinchey, "who loved the language and had a feel for the literary qualities of the texts especially Virgil", and who, while teaching his students Book IX of the Aeneid, repeatedly said "Och, boys, I wish it were Book VI' - which gave Heaney an interest in the book long before I ever read it" (Heaney and O'Driscoll, 2008, 296). This love of the language, and of Book VI of the Aeneid, remained with Heaney and became a touchstone in his life, and it is interesting that he sees "Route 110" very much in the context of Book VI, seeing the poem as tessaerically connected to its predecessor. Speaking of his translation of Beowulf, and of his protracted sense of this work as a task to be done, he noted, tellingly in the context of the argument of this essay, that: 
I didn't know or love Beowulf enough to remake it. If it had been a poem I'd internalized and lived with long and dreamily there might have been a chance of doing what I'd done with Buile Shuibhne in "Sweeney Redivivus" or have done, more recently, with Aeneid VI in "Route 110". I like that book of the Aeneid so much I'm inclined to translate it as a separate unit, as Sir John Harrington did in the seventeenth century. (Heaney and O’Driscoll 440)

In this poem, he is looking at the mosaic of his poetic life by focusing on the tesserae that comprise it and by looking at how those tesserae are connected in order to create the mosaic. Virgil's text provides that necessary aesthetic distance through which some form of transcendental perspective on the mosaic of his life can be achieved: it allows for further links and connections between the different historical selections, to use Hewitt's term, and for that extra layer of perspective on "the whole mosaic". He does this by combining them in a life-writing mosaic triggered, in retrospect, by the act of buying a book in a second-hand bookshop. He sees that this purchase can be viewed as the origin of a major strand of his future development in terms of offering a parallel path between the writings of Virgil and his own writings. Michael Parker cites an interview in which Heaney spoke of his own connection with Virgil: "I am very fond of Virgil in that he was obviously a bit like the scholarship boy who's made good. He was from the country in the North of Italy" (Dawe, 2008), and goes on to critique Heaney's view of their similitude noting that, far from being a scholarship boy, "Virgil was close to the political establishment at the outset of his, as a result of his friendship with Octavian, the future Emperor Augustus, and other leading Romans like Maecenas, who acted as his patron" (Parker, 2013, 375). I think Parker is correct, but what is actually happening here is that Heaney is symbolically connecting their lives because it is a willed connection, or a motivated selection.

Indeed, so strong is that connection that in 2016, posthumously, a full translation of Book VI on which Heaney had been working just before his death was published posthumously. Clearly a labour of love, he refers to the connections between this book and "Route 110":

The autobiographical sequence in twelve sections, published in Human Chain (2010), was entitled "Route 110" and plotted incidents from my own life against certain well-known episodes in Book VI: thus a bus inspector's direction of passengers to the bus for Route 110 - the one I often took from Belfast to my home in County Derry - paralleled the moment when Charon directs the shades on board his barge to cross the Styx; and a memory of the wake of a drowned neighbour whose body was not retrieved for three days shadowed the case of Aeneas' drowned, unburied helmsman Palinurus. It was a matter, in other words, of a relatively simple "mythic method" being employed over the twelve sections. The focus this time, however, was not the meeting of the son with the father, but the vision of future Roman generations with which Book VI ends, specifically the moment on the bank of the River Lethe where we are shown the souls of those about to be reborn and return to life on earth. (Heaney, 2016, vii) 
Here Heaney spells out, with typical understatement - the mythic method being used is far from simple - a very complicated series of connections and parallels between the Aeneid Book VI and "Route 110". The autobiographical mosaic of his poetic life then, necessarily includes Book VI, both in the original Latin and also in translation, and "Route 110", and these three tesserae will form a central part of the pattern that Heaney is carefully and almost pointillistically creating. The work of Virgil will serve for him as something of a textual unconscious which will allow him to voice feelings, thoughts and connections that are overtly difficult to express. His route to life writing will traverse both conscious and unconscious co-ordinates, and the starting point of this journey is a second-hand bookshop in Smithfield Market in Belfast, possibly "Henry Hall's" or "the U-Needa Book shop" (Heaney and O’Driscoll 49).

Trips to bookshops were commonplace for Heaney in his student years, both second- hand ones in Smithfield Market, and also Mullan's bookshop, but this one was highly significant. The opening poem of the sequence comprises, syntactically, two sentences. The opening, full of enjambment and parataxis, is almost breathless as the sepia-tinged memories of a special event are recalled. The physical features of the woman in the shop are unremembered, but the material smells of the shop are clear: "smelling of rot and disinfectant ... Dustbreath distilled in the cubicle mouth", as he bought "a used copy of Aeneid VI" (Human Chain 48). It is interesting that the olfactory sense is strong in both opening poems, as he recalls the "pet-shop / fetid with droppings" (Human Chain 49), and the specificity and materiality of the bag is significant in his recall:

I inhaled as she slid my purchase Into a deckle-edged brown paper bag....

.... hurried on, shortcutting to the buses, Parrying the crush with my bagged Virgil. (Human Chain 48-49)

The foregrounding of the "bag" is an index of ownership and possession as the classical distance of the book, written about a different time and in a different language has been familiarized by the possessive pronoun "my", and also by the rough edge of the bag, with its "deckle-edged" surface. The inhalation implies that not only has he taken ownership of the book, but also of the Benjaminian aura of the book in terms of smell. The importance of this purchase may have escaped him at the time, but in terms of writing his poetic life, it is a moment of some significance, as it sets the tone for a lifelong synaesthetic intoxication with the poem and its themes: "the motifs of Book VI have been in my head for years - the golden bough, Charon's barge, the quest to meet the shade of the father" (Heaney and O'Driscoll 389).

In any kind of life writing, the unconscious as well as the conscious needs to be given voice to offer a fuller picture of the mosaic in question. Here the experience is restored partially as the woman is metonymized in terms of her shop-coat and her clear-eyed version of working; the shop is recalled through the sense of 
strong smells, as indeed is the market itself. The woman is remembered as having a marsupial vent in her coat, and there seems to have been no conversational exchange. It is a moment captured in parts, in tesserae, which are connected in the memory of the speaker in the poem, the young Heaney, though of course, it is not the young Heaney per se, but rather a ventriloquized version of the young Heaney voiced by a writer of seventy or seventy-one, who is remembering the bookseller as a sibylline figure who is offering him a poetic path to the future wherein the classical tradition will form a significant area of interest. Indeed, her appearance from the depths of the "classics bay" is proleptic of the introduction of the sibyl in Heaney's full translation of Book VI. There are shades of "the Sibyl, Deiphobe, daughter of Glaucus, priestess / Of Diana and Phoebus" (Heaney Book VI 5) here, and her "vast scaresome cavern, / The Sibyl's deep-hidden retreat" (Heaney Book VI 3).

The Sibyl has access to occluded knowledge, in our terminology, the unconscious, and the "used copy of Aeneid VI" is some kind of conduit towards such unconscious knowledge. For Freud, and indeed Lacan, the unconscious itself "is memory, a storehouse of traces, inscriptions, remembrances, fantasies. And this memory, traumatic and fractural though it may be, must be underlaid, re-membered, by a subject to whom and in whom it represents itself" [italics original] (Borch-Jacobsen, 1992, 20), and in this case Heaney represents himself both literally and figurately setting out on a journey with Virgil. This parallels the way in which Virgil sets out on a journey with another influential figure in the Heaney canon, Dante, and the tesserae are connected in his dash through Smithfield market, with his "bagged Virgil" serving as a form of battering ram "parrying the crush", and warding off anything that will deflect Heaney from his chosen path. He compares the racks of suits and overcoats in the stalls, which swayed when one was "tugged from its overcrowded frame", to "their owners' shades close-packed on Charon's barge" (Human Chain 49), though it is probably not a comparison that would have struck the young Heaney as he ran to catch his bus; however, in retrospect, it is another connection between his own life and Book VI that strikes the older poet, who has a better, if still not perfect, view of the mosaic of his own life. It is also proleptic of the theme of death in the sequence. Of course, formally all of these sections are connected to Dante, as it is the poetic form of an altered terza rima, mostly unrhymed tercets with a lot of enjambment and also a lot of tension between the three structural forms: the stanza, the syntax and the thought process, and so Dante haunts this poem formally, just as Virgil haunted the Divina Commedia as Dante's guide, and just as Virgil also haunts this poem. Structurally, formally and thematically, the tesserae combine to create a nuanced and complex mosaic.

Heaney's own journey also serves to unite the tesserae of his younger and older selves as he is able to look back on different experiences from a more transcendental perspective, and to see the meaning that they had in his later life. This is yet another part of the complex mosaic that is created in "Route 110". Sections III and IV of the sequence foreground that journey motif, and again, it is a bifurcated journey 
as he goes by bus to get home, and then goes by plane to a wedding in Italy, a place with which his intellectual self is very familiar as it is the locus amoenus of Virgil's Aeneid and his Eclogues. The journey motif, itself a mainstay of life writing, is strong here as once the journey locations began to roll in their panels (in a notice board on the bus), then "everything / Came to life" (Human Chain 50). Heaney recalls items of clothing - an old "railway guard's long coat" and then bought specially for a wedding in Italy, "a wedding guest's bargain suit / Of finest weave, loosefitting, summery, grey", and the colour here is effortlessly segued into a connection with Virgil, as the reading and the actual physical presence are fused through the enjambment that begins the poem's final tercet:

...summery grey

As Venus' doves, hotfooting it with the tanned expats

Up their Etruscan slopes to a small brick chapel

To find myself the one there most at home. (Human Chain 51)

These doves are significant in Book VI as they are sent by Venus, Aeneas's mother, as guides to help him to find the golden bough:

And almost immediately

A pair of doves chanced down from the sky

In full view, and settled on the green grass;

In them the great hero knew his own mother's birds

And prayed and rejoiced: 'O, if a way can be found.

Be you my guides.' (Heaney Book VI 12-13)

So, while Heaney is at home in the mythological world of the Aeneid, he is also the most at home in the country of that book, as he has a prior sense of the palace and a fondness for it. The doves perhaps are a guide to him as much as to Virgil, and that interconnection of tesserae that began in the second-hand bookshop in Smithfield market, is furthered in this Italian trip.

The connection in question is overtly made in the inter-sectional enjambment that connects the learned world of Virgil with the lived world of the young Heaney, as he begins section $\mathrm{V}$ with an ungrammatically correct question:

Venus' doves? Why not McNicholls' pigeons

Out of their pigeon holes but homing still?

They lead unerringly to McNicholls' kitchen

And a votive jampot on the dresser shelf. (Human Chain 52)

Here, through the conflation of the exotic Classical doves with the more homely and familiar pigeons, Heaney is engaging in that form of conscious and unconscious connection that is at the core of life writing, and he is also making use of the poetic structure of the sequence to flag the associative nature of his thinking. The question with an elided verb that begins section $\mathrm{V}$ is a response to line ten of the 
previous section; as such, it is a form of sectional and stanzaic enjambment that actually breaks the syntactic, but not poetic, rules of enjambment. Generally, this term means that the thought-process of a part of the poem is not limited by the stanzaic conventions, but "runs on" across these breaks. In this poem, it is the poetic thought, as opposed to the syntax that runs on, cementing connections between the classical Rome of Virgil, and the McNicholls family farm which was across the road from Heaney's childhood home. Michael R Molino has made the intertextual connection between this poem and:

D. H. Lawrence's poem "Bavarian Gentian," converting the affirmative grasp of the flower-torch in Lawrence's poem to a negative "reach me not a gentian but stalks" of oats that, wrapped in foil from candy bars by McNicholl's wife, light his way into the "age of ghosts" at the poem's midpoint. The poem's final sections are announced as "age of births" (Molino, 2016, 102).

The pigeon/dove connection may have an additional biographical connection, as it was the daughter of this family, Philomena, "by then one of 'the big girls' had been put in charge of me during those first days" of attending Anahorish national school (Heaney and O'Driscoll 242). So just as the doves showed Aeneas the correct path to the golden bough, so these pigeons helped the young Heaney to his own golden bough of education, reading, and ultimately, poetry. Book VI is the pace where Aeneas visits the shade or ghost of his dead father Anchises, and Heaney will also look to ghostly presences and hauntings in "Route 110", because as we get older, more and more of our friends, family and acquaintances have become ghostly remembered figures.

Clearly the term tessera is quite protean, and yet in all of its significations, it is relevant to the mosaic that is being made out of Aeneid Book VI, Heaney's translation of that book and "Route 110". Given that Book VI is about a visit to the underworld, it is appropriate that ghostly hauntings of the dead appear in Heaney's poem and indeed they do, as living and dead, memory and the past are fused and blended together. Heaney remembers the funeral of Michael Mulholland, another neighbour, as the first one that he "attended as a full participant" (Human Chain 53), as he had drowned while swimming the Bristol channel. Interestingly, having flagged the Virgilian connection of this incident with the drowning of Aeneas' drowned, unburied helmsman Palinurus, Heaney "makes no allusion to this Virgilian parallel in the text" (Parker, 2013, 377). The only parallel is that Aeneas has promised his crewman that people will "discover and honour his corpse so that his spirit can then duly cross the Styx. Heaney, in his turn, bears witness at the ceremony for his drowned friend, body now recovered, so that he too can fulfil his further destiny" (Putnam, 2012, 91). The connection of a new sense of adulthood with a funeral is an interesting echo of the Virgilian text, but of course it is also an index of how death has always been quite a social event in Ireland, with the idea of a "wake" being a very Irish ceremony, and one where the conversation is "kept going" (Human Chain 53). 
In section VI, the sense that death is part of life, that it is part of a continuum that was so prevalent in classical literature, where the underworld had as strong an existence as this world, is flagged in the oxymoronic opening line: "The corpse house then a house of hospitalities", while the sense of recalling an experience whose meaning had been missed at the time is clear from Mrs Mulholland's pointing him towards "a right of way" that would facilitate his journey home (Human Chain 54). Clearly this sense of adult formality, associated with this funeral, has been a point of significance for Heaney, and like McNicholl's pigeons, he sees how many guiding hands have led him towards his chosen path; indeed the "mother" could well be another avatar of the Sibylline figure of Book VI. The next section looks at loss and ghostly figures and indeed it begins with a haunting appropriation of some lines from Book VI:

As one when the month is young sees a new moon Fading into daytime, again it is her face At the dormer window, her hurt still new. (Human Chain 55)

By italicising the line, Heaney signals that it is a quotation, but he does not provide any source. However, Michael Parker and Michael R. Molino have both commented on the actual source. Molino notes that Heaney 'uses a portion of lines 524 and 525 from Robert Fagels' translation, but reverts to his own words in the enjambment' (Molino 102). Fagels' translation (cited by Molino) reads: "as one when the month is young may see or seem to see the new moon rising up through banks of clouds" (Virgil 346). Michael Putnam offers a lucid and valuable account of these lines:

It is to death, and to Virgil's tour of its domain, that Heaney returns us at the opening line of section viii: "As one when the month is young sees a new moon." The line is among the most striking in the poem. It initiates a new segment but it is also a close rendering of a stunning hexameter in the Aeneid where, in the great wood haunted by the suicides, the hero discerns the dim ghost of his former lover Dido. (Putnam 92)

In terms of the grammatological shape of the lines on the page, the movement from italics to normal font enacts the switching or duality between the two works visually and poetically. In the italicised line, the referent is Dido; in the unitalicized line, the reference is a former girlfriend of Heaney. One is dead while the other is lost to the poet, but in the life writing mode of the poem, both of these women are in the past and are now on the shores of Lethe in that they are ghostly flickers of memory; instances of remembered experiences; and glimmers of regret and loss. The lines fuse the image of Aeneas seeing Dido dimly through the mist, and Heaney recalling the face of a former girlfriend whom he has hurt. Loss is the connection between the two, and it is captured in this very economical poem which is just one sentence in length. The form is useful here as the stanza breaks allow for a pause in the flow of parallelisms between Aeneas and the young 
Heaney; Lethe and the past in Northern Ireland; Dido and the former girlfriend; Latin translation and contemporary English; as well as in the conflation between the twin perspectives of Aeneas and the young Heaney. The unrhymed tercet form is also thematically appropriate, as it is a fusion of the classical Italian poetic form with a more sinewy, contemporary English version, and even as it is written, it conflates Dante, Virgil and Heaney so the tesserae are again being reconfigured into a more complete and nuanced verbal mosaic.

If section VII focused on Eros, then the following section will focus squarely on Thanatos; as love and death gradually become the framing points of the lifejourney that is the subject of this poem. Section IX is more overt in terms of loss, looking at deaths by violence, and deaths, to return to an earlier phrase, of people who could be seen as innocent bystanders:

\author{
And what in the end was there left to bury \\ Of Mr Lavery, blown up in his own pub \\ As he bore the primed device and bears it still \\ Mid-morning towards the sun-admitting door \\ Of Ashley House? Or of Louis O’Neill \\ In the wrong place the Wednesday they buried \\ Thirteen whod been shot in Derry? (Human Chain 56)
}

John F. Lavery was a sixty-year-old Catholic, "who owned a pub on a junction of the Lisburn Road in south Belfast, a mere twenty yards or so from the Heaneys' house at 16 Ashley Avenue. He died at around 11.30a.m. on 21 December 1971, while trying to remove from the premises a 20lb bomb which had been deposited there in all probability by the Provisional IRA" (Parker, 2012, 337). The proximity of the pub to Heaney's own home, and the random nature of the death of someone who was not involved in the conflict, was clearly something that resonated with Heaney, as did the death of another man, the unnamed subject of the elegy "Casualty" in Field Work (Heaney Field Work 21-24), Louis O'Neill, a fisherman and an acquaintance of Heaneys who frequented his father-in-law's pub in Tyrone. He was killed in the reprisal bombing of a Protestant pub, "having disobeyed a curfew set by his fellow Catholics after the Bloody Sunday Massacre" (Tobin, 1999, 143). These are more deaths without bodies, harking back to Michael Mulholland, but in a far more violent context. Both of these men were scattered in death; they were "bodies / Unglorified" that were "bagged / Behind the grief cordons" (Human Chain 56). For both of these men, innocent bystanding meant death, and not the death of someone like Anchises in Book VI who is honoured and glorified; these men were anonymous until their poetic rebirth in this poem. Heaney reclaimed them, and through naming them, gave them a form of afterlife that parallels the afterlife that Aeneas will find when he goes to meet his own father, something implied by the term "bagged", which recalls the earlier "bagged Virgil". 
In the final lines of the section, Heaney probes the irony that the groups involved in the killings and bombings - the Provisional IRA most notably, as well as the Ulster Volunteer Force and British Army - all had the ability to give their dead formal and reverent obsequies. IRA funerals at the height of the troubles were very well-attended, and there was music, speeches and a volley of shots fired over the grave. Even in 2020, the death of a former significant figure in the Provisional movement, Bobby Storey, resulted in a funeral that violated a lot of the rules of the Covid-19 lockdown: clearly Sinn Féin felt it would be worth the criticism to honour one of their senior figures. The same is true of Loyalist paramilitary figures, members of the British Army and the Royal Ulster Constabulary. The end of the poem sees a similar enjambment, but not one that allows for a smooth transition, but rather one that stresses the ironic contradiction of burial in the troubles. Heaney, very aware of the funeral pieties of Irish country life, as we saw in the Michael Mulholland funeral, is acerbic about the contrast between the ugly and almost anonymized deaths of O'Neill and Lavery, and the political formality of the funeral rites of those who killed them:

not to be laid

In war graves with full honours, nor in a separate plot

Fired over on anniversaries

By units drilled and spruce and unreconciled. (Human Chain 56)

The term "spruce" is particularly jarring here. It refers to someone who is fashionable or smartly dressed, and so is related to physical appearance, and the irony of people who caused the scattering of the bodies of O'Neill and Lavery looking fashionable at funerals of their own members is tellingly encapsulated in this word. This is further contrasted when we look at the funeral pieties of the Aeneid, as Aeneas sets out to mourn Misenus:

when the weeping was over, they laid him out On the ritual couch, his remains swathed in purple, Familiar robes of the dead. (Heaney Book VI 14)

This would seem to have little in common with the scattered bodies of O'Neill and Laverty, but as so often happens in this poem, contrasts become comparisons through connections. It is suggested that what has made Misenus remembered is his magnificent tomb on the hill, "which is now called / Misenus, a name that will live down the ages" (Heaney Book VI 14). The irony here is that what actually makes Misenus famous and almost immortal is not the hill or the tomb, but rather the fact that he is recalled in the Aeneid, and the same is true of Louis O'Neill and John Lavery: their immortality, like that of Misenus, is due to their place in this poem. Immortality comes from language and memory as opposed to anything else, so the aporia is that the paramilitaries who had the "full honours", are now anonymous and forgotten except by their own comrades, while the victims, the 
innocent bystanders who were "blown to bits" (Field Work, 1979, 22), have now a memorial that will reach a far broader audience. People who read Human Chain, and who never met these two men, now know of them, and feel an empathy for their violent and unnecessary deaths. The people who killed them are now anonymous and their memories are scattered. In death, and through this poetic rebirth, the bodies are revivified and rendered whole in their poetic existence.

It could be said that these two very locally-known men, who had no national profile, or overt political agency, have been reborn in this poem as emblematic figures of the pointlessness and material waste of the conflict in Northern Ireland. Heaney avoided overt political commentary across the full range of his work, but his views on violence were voiced in both poetry and prose, as he was increasingly appalled by the death toll. The connection with the Aeneid as a textual unconscious allows him a real platform for such a poetic process of rebirth as in the next section, we see the souls on the Elysian Fields, who are all waiting to be reborn, and these follow directly on from the reborn figures of O'Neill and Lavery in a poetic linkage wherein the tesserae of O'Neill, Lavery, Dido and Orpheus are conjoined across Sections IX and X of the poem. Virgil's art allowed for a continuum between life and death and rebirth and in a time of violence, it would be both assuaging and comforting to think that the dead were still alive in some way. This book, with its title stressing connection, also looks at a chain - not the strictly stratified chain of the underworld and mortality that underpinned classical eschatology, but a less formal but insistent one, where language and art allow for the shattered bodies of innocent bystanders to be healed and annealed in language and memory, and through this process sanction a form of poetic or artistic rebirth for both men.

In a time when the afterlife is not as much a feature of most people's mental map, by using the Aeneid as a point of reference, Heaney can offer some of the comfort of that classical clearly-defined sense of immortality to the contemporary consciousness. Earlier in the book, Heaney has made the connections between Ancient Greek traditions and the contemporary world overt. He has made the point that he will "confound the Lethe in Moyola", with the two rivers standing in synecdoche for their relative cultures:

Ask me to translate what Loeb gives as

'In a retired vale ... a sequestered grove'

And I'll confound the Lethe in Moyola

By coming through Back Park down from Grove Hill

Across Long Rigs on to the riverbank -

Which way, by happy chance, will take me past

The domos placidas, those peaceful homes

Of Upper Broagh. (Human Chain 46)

His aim is to "confound" both places, and the term itself is interesting: "confound" means "to confuse" or "to put to shame", and this seems to be at 
odds with his purpose. It would seem that the term "conflate" would be more apt, as it means "to fuse together", and that seems to be what he is doing (and it also fits the rhythm of the poem). However, if we look to the etymology of the word, things become clearer. The word derives from the Latin confundere, meaning "to pour together, blend, bring into disorder, destroy, disconcert", and this in turn derives from the compound "con" and "fundere", meaning "to pour, shed". It is at this level of the textual unconscious that the word "confound" operates, as Heaney, having set out the twin tracks of the Aeneid and his own life, now pours them together in a way which will confuse and disconcert a more contemporary opinion, as he imagines art as a soothing force which allows memory to anneal and heal the strictures of the actual world in all its violence. Lethe of course is the river of forgetfulness, which "Heals ... anxieties and obliterates / All traces of memory" (Heaney Book VI 38), and there is a hint here of an art that is attempting to assuage the memories of lives shattered (literally) by violence, and perhaps to usher in a rebirth wherein such violence will no longer be hegemonic, as it had been in Northern Ireland for so long.

Thus, in section X, he sets up a diptych between Lethe and Moyola. He begins with an image of the Elysian fields, where "Virgil's happy shades" who are "wrestlers, dancers, runners on the grass", contend on "green meadows":

while Orpheus

Weaves among them, sweeping strings, aswerve

To the pulse of his own playing. (Human Chain 57)

These souls, about to be reborn are happy and joyful and secure in their new life that is to come, with the music of Orpheus standing as a metonym for the healing power of art. In the last line of the second tercet, a rhetorical, temporal and spatial swerve takes place in a sentence which takes the previous sentence about the Elysian fields as its subject:

Not unlike a sports day in Bellaghy,

Slim Whitman's wavering tenor amplified ...

And teams of grown men stripped for action

Going hell for leather until the final whistle,

Leaving stud-scrapes on the pitch and on each other. (Human Chain 57)

Seeing Slim Whitman as an Orphic figure may seem to be stretching the connection a little, but for Heaney the essence is the same. For the better part of Heaney's life, when people thought of Northern Ireland, they thought of violence; he on the other hand, thinks of a sports day in Bellaghy, County Derry where the only violence is that of competition on the football field, in this case probably Gaelic football. This violence is culturally-sanctioned and will not result in death. It is another image of that rebirth of which he is speaking, as the bodies, 
while stud-scraped, are whole and integral and not scattered like the innocent bystanders of the earlier section.

In the following section, he is fishing on the edge of the Moyola, possibly with his father (Putnam 96) (Parker 'Back in the Heartland' 381). The opening line 'Those evenings when we'd just wait and watch' (Human Chain 58), mirrors in rhythm one of his most famous opening line "When all the others were away at Mass" (Heaney The Haw Lantern 27) both metrically and syllabically (through the mirroring is not absolute): one is addressed to his dead mother while this one is addressed to his dead father. In addition, the conversation with the dead father is very much at the core of Aeneid Book VI, so this moment of connection parallels the end of that book where Aeneas and his father meet for a brief moment. The parallel is further developed as in the Aeneid, the vision of the souls awaiting to be reborn, "humming with life" as narrated by Anchises, is compared in metaphor to:

bees in meadows

On a clear summer day alighting on pied flowers

And wafting in mazy swarms around white lilies. (Heaney Book VI 38)

In "Route 110", there are no bees, but there are midges, and a reference to other ghostly figures:

Of the riverbank field, twilit and a-hover

With midge-drifts, as if we had commingled

Among shades and shadows stirring on the brink

And stood there waiting, watching,

Needy and ever needier for translation. (Human Chain 58)

The term "commingled" is significant here as it has resonances of the earlier "confounded" as well as connecting Heaney and his father with Aeneas and his father - "shades and shadows" - while the term "brink" is polysemic: referring both to the brink of the river Moyola and also that of Lethe, as the mosaic of Lethe and Moyola becomes clearer as river pours into river in such a way as to make them undistinguishable. The final word of the poem, "translation;" is almost a breaking of the fourth wall as we have already noted that Heaney sees "Route 110" as in some ways a translation of Book VI, and here he is overtly making this point.

In the final poem, the trope of rebirth, which has been a central strand in the sequence, is now made actual as the new grandchild, Anna Rose, is born: an age of ghosts is transmuted into an age of births. The rebirth here is more symbolic than actual, and the metempsychosis is not as planned as that in the Aeneid. Rather, the new baby is born into a world where the violence in Northern Ireland that killed John Lavery and Louis O'Neill, is no longer a constituent factor. However, the connection with the previous section of the souls in Elysium is overt: "one / Whose long wait on the shaded hank has ended" (Human Chain 59). The influence of Heaney's father is in her both culturally and genealogically, 
and she symbolises a hope for the future, a hope that is grounded in the past and in culture. The phrase "drink and smoke" reflects "the mention of cigarettes and smoke imbued clothes which are particulars of the wake of Michael Mulholland as described in part vii. Death has now yielded to new life. The mother of the dead swimmer has been replaced by the mother of the newborn" (Putnam 106).

This sense of the future is captured in language. While so much of the language of the sequence has been driven, both implicitly and explicitly, by forms of translation from Latin to English, which sees the language of the present in some ways governed by the language of the past, the poem ends with a discourse of the future. The final language of the poem is one in which neither poet nor reader is fluent nor expert: it is, rather, a language that will have to be learned as the future develops by all, with no dictionary or grammar book to guide in this process. It is the language which will herald the transformation from an "age of ghosts" to an "age of births" (or rebirths); it is the language of the future:

I arrive with my bunch of stalks and silvered heads

Like tapers that won't dim

As her earthlight breaks and we gather round

Talking baby talk. (Human Chain 59)

In this climactic stanza, we see the different meanings of the tessera coming together in a polysemic constellation. The tesserae formed by the mosaic of Heaneys classical reading and his contemporary experience, are seen as a pattern by their interaction through translation, which provides a perspective on both: Hewitt's "whole mosaic" of which we spoke earlier. The classical and the experiential are also the two sides of the "tessera hospitalis", in Gadamer's terms, wherein there is a recognition of a connection, of a pattern, when different parts are brought together, and in this case that pattern is of the interchange of life and death; of past and present, and of the present as haunted by the past through conscious and unconscious memory. It allows for connections between $\mathrm{Mr}$ Lavery and Anna Rose; between Heaney's early girlfriend and Dido; and between the Elysian fields and a field in Broagh. In this poem, the tessera connects all of these areas into a mosaic and translation provides that necessary perspective from which a pattern can be observed symbolically, recalling the Lacanian notion of the tessera, which functions as a form of password, what Lacan has termed a "sum bolon", and he went on to point out that a "central concept involved in the symbol is that of a link" (Écrits 786). In Bloomian terms, Heaney's own work in some way "completes" that of Virgil (Bloom, 1973, 67), creating a new pattern and again, offering a different perspective which allows for greater breadth and clarity of vision. The logic of the tessera helps to make something whole out of part; something present out of the past, and finally from the ancient classical language of Latin comes a new language, a language of the future as ghost talk swerves into "baby talk", and the pattern that connects these books is one that moves from "an age of ghosts" to "an age of births". 


\section{Works Cited}

Bloom, Harold. The Anxiety of Influence: A Theory of Poetry. Oxford University Press, 1973.

Borch-Jacobsen, Mikkel. The Emotional Tie: Psychoanalysis, Mimesis, and Affect. Translated by Douglas Brick and others. Stanford University Press, 1992.

Dawe, Gerald. The Poetry Programme. RTE Radio 1, October 4, 2008.

Easthope, Anthony. The Unconscious. Routledge, 1999.

Evans, James Allan, editor. Arts \& Humanities through the Eras Ancient Greece and Rome 1200 B.C.E. -476 C.E., vol. 2. Thomson Gale, 2005.

Freud, Sigmund. New Introductory Lectures on Psychoanalysis, vol. 22, Hogarth Press, 1933.

Gadamer, Hans-Georg. The Relevance of the Beautiful and Other Essays. Edited by Robert Bernasconi. Translated by Nicholas Walker. Cambridge University Press, 1986.

Heaney, Seamus. Field Work. Faber, 1979.

. Station Island. Faber 1984.

. The Haw Lantern. Faber 1987.

. The Spirit Level. Faber, 1996.

. Human Chain. Faber, 2010.

. Aeneid Book VI. Faber, 2016.

Heaney, Seamus and Dennis O'Driscoll. Stepping Stones: Interviews with Seamus Heaney. Faber, 2008.

Heininger, Joseph. 'Making a Dantean Poetic: Seamus Heaney's "Ugolino"' New Hibernia Review, vol. 9, no. 2 (Summer), 2005, pp. 50-64.

Lacan, Jacques. Écrits: The First Complete Edition in English. Translated by Bruce Fink in collaboration with Héloïse Fink and Russell Grigg. W. W. Norton, 2006.

The Four Fundamental Concepts of Psycho-Analysis. Translated by Alan Sheridan. Hogarth Press, 1977.

Seminar 7 The Ethics of Psychoanalysis, 1959-1960. Translated by JacquesAlain Miller, Tavistock/Routledge, 1992.

Matthews, Steven. Irish Poetry: Politics, History, Negotiationthe Evolving Debate, 1969 to the Present. Macmillan, 1997.

Molino, Michael R. “The Freed Speech of "Equivocal Words": Seamus Heaney's Door into the Light." "The Soul Exceeds Its Circumstances": The Later Poetry of Seamus Heaney, edited by Eugene O’Brien. Notre Dame University Press, 2016, pp. 898106.

O'Donoghue, Bernard. Seamus Heaney and the Language of Poetry. Harvester Wheatsheaf, 1994.

Ormsby, Frank, editor. The Collected Poems of John Hewitt. Blackstaff Press, 1991.

Parker, Michael. "Back in the Heartland": Seamus Heaney's "Route 110" Sequence in Human Chain'. Irish Studies Review, vol. 21, no. 4, 2013, pp. 374-386.

"His Nibs": Self-Reflexivity and the Significance of Translation in Seamus Heaney's Human Chain. Irish University Review, vol. 42, no. 2, 2012, pp. 327-350.

Putnam, Michael C. J. 'Virgil and Heaney: "Route 110"' Arion: A Journal of Humanities and the Classics, vol. 19, no. 3 (Winter 2012), 2012, pp. 79-108. 
Singer, Alan. Aesthetic Reason: Artworks and the Deliberative Ethos. Pennsylvania State University Press, 2003.

Thwaites, Tony. Reading Freud: Psychoanalysis as Cultural Theory. SAGE Publications, 2007.

Tobin, Daniel. Passage to the Center: Imagination and the Sacred in the Poetry of Seamus Heaney. University Press of Kentucky, 1999.

Tochigi, Nobuaki. 'Poetry Redressed, or the Resilience of Language in Seamus Heaney's "Squarings". The Harp, vol. 9, 1994, pp. 73-82.

Virgil. The Aeneid. Translated by Robert Fagels. Viking, 2006.

Recebido em: 04/01/2021

Aceito em: 06/04/2021 